\title{
THE EFFECTIVENESS OF GELUGUR ACID (Garcinia atroviridis) MARINADE ON THE PHYSICAL QUALITY OF CULLED CHICKEN MEAT
}

\author{
Peni Patriani*1), Harapin Hafid ${ }^{2}$ \\ ${ }^{1)}$ Department of Animal Husbandry, Faculty of Agriculture, Universitas Sumatera Utara, Padang Bulan, \\ Medan 20155, Indonesia \\ ${ }^{2)}$ Faculty of Animal Science, Halu Oleo University, Jl. H.E.A Mokodompit Kampus Anduonohu, \\ Kendari93232, South East Sulawesi, Indonesia \\ *Corresponding Email: penipatriani@usu.ac.id
}

Submitted 28 March 2021; Accepted 31 May 2021

\begin{abstract}
A method to improve the physical quality of culled chicken meat is required due to the tough texture and faint color of culled chicken meat. High protein content in culled chicken meat makes it easy to experience quality degradation. One of the methods to maintain the quality of post-harvest chicken meat is using spices. Gelugur acid (Garnicia atroviridis) is a spice for cooking spice, sweets, herbs, deodorizing fresh fish, and even cleansing fish before it proceeds into the processing stage. This study aimed to determine the concentration of Garcinia atroviridis which is effective to improve the physical quality of culled chicken meat. This study used a randomized design with 4 treatments and 5 replications. The treatments consisted of T0: without marination using Garcinia atroviridis (as control), T1: marination in $50 \mathrm{~g}$ of Garcinia atroviridis $+1000 \mathrm{~mL}$ aquadest, T2: marination in $50 \mathrm{~g}$ of Garcinia atroviridis $+750 \mathrm{~mL}$ aquadest, T3: marination in $50 \mathrm{~g}$ of Garcinia atroviridis $+500 \mathrm{~mL}$ aquadest. The parameters were the physical quality of meat consisting of meat $\mathrm{pH}$, water holding capacity, tenderness, cooking loss, drip loss and meat color. Based on the results of the study, Garcinia atroviridis marinade had significant effect $(\mathrm{P}<0.05)$ on the $\mathrm{pH}$ value of the meat, cooking loss, drip loss, tenderness, water holding capacity, and meat brightness. It was concluded that the marination of meat at concentration of $50 \mathrm{~g}$ of Garcinia atroviridis $+1000 \mathrm{~mL}$ aquadest (T1) was effective in maintaining the $\mathrm{pH}$ value, reducing meat drip loss, increasing water holding capacity, increasing tenderness, brightening the color of the meat and maintaining the freshness of the refined culled chicken meat. Marination of meat in concentration of $50 \mathrm{~g}$ Garcinia atroviridis $+750 \mathrm{~mL}$ aquadest (T2) was also effective in reducing cooking loss of culled chicken meat.
\end{abstract}

Key words: Acid; concentration; marination; storage; spices 


\section{INTRODUCTION}

Culled chicken is poultry that productivity has decreased but still can be used as a food. However, culled chicken meat tends 1 to have a tough texture and faint color. Therefore, it is necessary to consider the physical quality of chicken meat before processing it. So that the quality of culled chicken meat needs to be improved in order to increase the satisfaction of consumers. One of the methods that has been known to improve the physical quality of culled chicken meat is using abundant and relatively low priced ingredients. Prasetyo et al. (2013) stated that physical properties of meat are very important in the processing because these can determine the quality and type of processing.

A natural ingredient that may improve the quality of meat is gelugur acid (Garnicia atroviridis) that is known as a spice and herb in Indonesia. Gelugur acid (Garnicia atroviridis) is a spice used as a cooking spice, sweets, herbs, deodorizing fresh fish, and even cleansing fish before it proceeds into the processingstage. According to several previous research sources Garcinia atroviridis contains antioxidants (Abdullah et al., 2013; Al-Mansoub et al., 2014). Garcinia atroviridis contains citric and ascorbic acid Alisha et al. (2020). Garcinia atroviridis also has sour taste that could help to break down the protein structure of the meat. Nurwantoro et al., (2012) revealed that acidic marinade can be used for tenderizing meat. Marination with acids can be performed for 6 to $24 \mathrm{~h}$ so that acid in marinade can cleave the peptide bonds in the protein fiber of meat.

Physical quality of meat includes $\mathrm{pH}$ value of meat, water holding capacity, tenderness, cooking loss, drip loss, and meat color. The $\mathrm{pH}$ value of meat depends on the

*Corresponding author:

Peni Patriani

Email: penipatriani@usu.ac.id

Department of Animal Husbandry, Faculty of Agriculture, Universitas Sumatera Utara, Padang Bulan,

Medan 20155, Indonesia amount of glycogen contain in meat. Wideman et al. (2016) stated that chicken meat color variations are related to $\mathrm{pH}$ and myoglobin values. The normal $\mathrm{pH}$ value of 5.5 meats can be acquired after the rigormortis process. The decrease in $\mathrm{pH}$ of meat can cause protein denaturation with strong acid pressure so that the marination time needs to be limited. Normal $\mathrm{pH}$ value of meat is 5.4-5.8.

Water holding capacity is the ability of meat to hold water. Water holding capacity is influenced by $\mathrm{pH}$ value, proteolytic and protein oxidation. In previous research, marinated meat caused an increase in the value of water holding capacity (Kaewthong and Wattanachant, 2018). Cooking loss is the percentage of weight loss in meat due to the cooking process. Cooking loss can be evaluated by changing the sample weight before and after cooking. The higher cooking loss value, the lower quality of the meat will be.

Also the higher cooking loss, the less nutritional content in the meat. Zhang et al. (2020) stated that marination can reduce cooking loss in broiler chicken breasts. In general, cooking loss in meatrange from 15$40 \%$. One of the criterias in assessing the quality of meat is tenderness. Differences in meat tenderness can be caused by differences in the size of the myofiber. The Increasing of myofiber diameter has negative potential to meat tenderness. The tenderness of the meat can be seen by measuring the breaking strength of the fiber, the lower breaking power value, the more tender meat becomes and the higher breaking power value, the tougher meat becomes.

Meat tenderness is also associated with the high $\mathrm{pH}$ of the meat (Lomiwes et al., 2014). Drip loss is thewater droplets that come out of the meatduring the

How to cite:

Patriani, P., \& Hafid, H. (2021). The Effectiveness of Gelugur acid (Garcinia atroviridis)Marinade on the Physical Quality of CulledChicken Meat. Jurnal Ilmu dan Teknologi Hasil Ternak (JITEK), 16 (2), 105-116 
storage process. High drip loss values are associated with low water holding capacity. The high drip loss value can reduce the quality of meat due to the amount of water that drips out with the nutrients in themeat. Meats are measured, hung first and weighed (Berry et al., 2008). The color of free-range chicken meat tends to be dark andyellowish. In general, marination using acids will give the meat a brightening effect.Bright colored flesh is preferred because it looks cleaner. The color of the meat is influenced by the amount of myoglobin and high $\mathrm{pH}$ (Wideman et al., 2016).

Improving the meat quality after slaughtering becomes a priority in order to improve quality during processing. The physical quality of meat is also important to know that meat is suitable for consumption. Garcinia atroviridis has previously been studied in fish and processed products but has not been applied to livestock products for instance meat. The physical quality of meat can be determined by testing $\mathrm{pH}$, water holding capacity, tenderness, cooking loss, drip loss, and meat color. This study aimed to determine the effective concentration of Garcinia atroviridis marinade on the physical quality of culled chicken meat.

\section{MATERIALS AND METHODS}

This research was conducted from May to July 2020 at the Animal Husbandry Laboratory, Animal Husbandry Study Program, Universitas Sumatera Utara. This research was carried out in experimental laboratory. The tools and materials used in the study were Garcinia atroviridis, culled chicken meat, aquadest, $\mathrm{MgO}$, analytical scales, rope, wire, glass plate, stainless steel pan, gas stove, stopwatch, penetrometer, Amtast AMT16M type $\mathrm{pH}$ meter, Konika Minolta colorimeter, cooling rack, whatman paper no 41, load $35 \mathrm{~kg}$, stirring rod, plastic, wire, ruler, thermometer, measuring cup and hanging wire.

\section{Research Design}

This study used completely randomized design with 4 treatments and 5 replications. The treatment $(\mathrm{T})$ consists of:

T0: no marination using Garcinia atroviridis (as control)

T1: marination in $50 \mathrm{~g}$ of Garcinia atroviridis $+1000 \mathrm{~mL}$ aquadest

T2: marination in $50 \mathrm{~g}$ of Garcinia atroviridis $+750 \mathrm{~mL}$ aquadest

T3: marination in $50 \mathrm{~g}$ of Garcinia atroviridis $+500 \mathrm{~mL}$ aquadest

In this study 80 weeks old culled chicken meats used as samples and each sample weight $20 \mathrm{~g}$. The marinade for each treatment was made by boiling $50 \mathrm{~g}$ of Garcinia atroviridis + aquadest at $100{ }^{\circ} \mathrm{C}$ for $15 \mathrm{~min}$. The sample of culled chicken meat in each treatment was immersed in the marinade for $60 \mathrm{~min}$ at room temperature of $27^{\circ} \mathrm{C}$ and then left for $24 \mathrm{~h}$. After $24 \mathrm{~h}$, the physical properties of the meat were observed as to $\mathrm{pH}$, water holding capacity, tenderness, cooking loss, drip loss, and meat color. The data obtained were then analyzed with analysis of variance, if it shows significant results, the data would be analyzed with Duncan test (Steel and Torrie., 1990). The program for data analysis was IBM SPSS statistical 21 License.

\section{Measurement of Research ParameterpH of Meat}

Measuring $\mathrm{pH}$ value using a calibrated Amtast type AMT16M pH meter. The $\mathrm{pH}$ meter was inserted into pieces of meat weighing $20 \mathrm{~g}$. The $\mathrm{pH}$ value can be read on the screen used (AOAC, 2005). The $\mathrm{pH}$ value of the meat will gradually decrease from a value 7 to the range of 5.3 to 5.7

\section{Water holding capacity}

The water holding capacity test was intended to determine the ability of the meat to bind free water. The marination was performed by immersing $20 \mathrm{~g}$ of meat in gelugur acid marinade. The Water holding capacity used the Hamm method is to prepare a $0.3 \mathrm{~g}$ meat sample that was 
placed on filter paper between steel plates which are loaded using a $35 \mathrm{~kg}$ load for
5 min. To measure water binding capacity canbe used the formula below:

Water content $=\frac{\text { wet area }(\mathrm{cm} 2)}{0.0948}-8.0$ then measured $:$ WHC $=1-\frac{\text { Expresed juice }}{\text { Water content }}$

\section{Cooking loss}

Cooking loss is the loss of meat weight after cooking. Cooking loss was calculated using the CSIRO method thatwas meat weighing $20 \mathrm{~g}$ and boiled at $80^{\circ} \mathrm{C}$ for

30 min then the meat was cooled and dried with a tissue and the final weight is weighed (Prayitno et al., 2020). Cooking loss can be calculated using the formula:

$$
\text { Cooking loss }=\frac{\text { Weight before cooking-Weight after cooking }}{\text { Weight before cooking }} \times 100 \%
$$

\section{Meat Tenderness}

Meat tenderness was measured organoleptically or using a penetrometer
(Hafid et al, 2020). Before measuring the cooked meat, then it is calculated using the formula:

\section{Tenderness $(\mathrm{mm} / \mathrm{g} / 10 \mathrm{~s})=\underline{\text { Average measurement weight }}$ 10 second}

\section{Meat Drip loss}

Drip loss can occur in chicken meat during the storage process. The drip loss test was carried out using the bag method by weighing the meat as the initial weight then stored by tied to a raffia rope and put into a plastic bag and hanging on a storage rack at $4^{\circ} \mathrm{C}$ for $24 \mathrm{~h}$ then the meat was weighed again as the final weight. Otto et al. (2004) states that driploss is calculated using the formula:

$$
\text { Drip loss }(\%)=\frac{\text { initial meat weight }- \text { final meat weight }}{\text { initial meat weight }} \times 100 \%
$$

\section{Meat color}

To analyze the color of culled chicken meat, it was carried out objectively at the shelf life of $24 \mathrm{~h}$ using a Konika minolta colorimeter. Firstly the equipment must be calibrated then fires light at the meat sample and reads the color value for $\mathrm{L}$ as the brightness color, $\mathrm{a} *$ as the meat color and $\mathrm{b}$ the yellowish color. The data can be $\mathrm{L} * \mathrm{a} * \mathrm{~b}$

* (Patriani et al., 2019)

\section{RESULTS AND DISSCUSION}

The measurement of the physical quality of culled chicken after marinating for 60 min and 24 can be seen in Table 1 .

Table 1. Physical quality of culling chicken after marination using Garcinia atroviridis

\begin{tabular}{ccccc}
\hline Parameter & \multicolumn{4}{c}{ Treatment of Garcinia atroviridis Concentration } \\
\cline { 2 - 5 } & $\mathrm{T} 0$ & $\mathrm{~T} 1$ & $\mathrm{~T} 2$ & $\mathrm{~T} 3$ \\
\hline Meat pH & $5.94 \pm 0.20^{\mathrm{a}}$ & $5.77 \pm 0.05^{\mathrm{b}}$ & $5.74 \pm 0.03^{\mathrm{b}}$ & $5.77 \pm 0.02^{\mathrm{b}}$ \\
Cooking loss (\%) & $28.31 \pm 0.93^{\mathrm{a}}$ & $25.76 \pm 0.67^{\mathrm{ab}}$ & $21.56 \pm 1.53^{\mathrm{b}}$ & $26.66 \pm 0.59^{\mathrm{a}}$ \\
Water Hoding Capacity (\%) & $38.22 \pm 1.18^{\mathrm{a}}$ & $42.58 \pm 1.88^{\mathrm{b}}$ & $50.08 \pm 1.20^{\mathrm{c}}$ & $54.06 \pm 3.62^{\mathrm{c}}$ \\
Drip loss (\%) & $3.35 \pm 0.45^{\mathrm{b}}$ & $2.40 \pm 0.26^{\mathrm{a}}$ & $2.91 \pm 0.75^{\mathrm{a}}$ & $3.79 \pm 0.08^{\mathrm{b}}$ \\
Tenderness (mm/g/ 10 ss) & $37.83 \pm 1.44^{\mathrm{a}}$ & $24.63 \pm 0.99^{\mathrm{c}}$ & $30.55 \pm 2.18^{\mathrm{b}}$ & $30.76 \pm 0.00^{\mathrm{b}}$ \\
\hline
\end{tabular}

Note : The means with different superscripts showed significant differences $(\mathrm{P}<0.05)$ 
The pH value of culled chicken after marination using Garcinia atroviridis

Based on the research results, it can be seen in Table 1 that the highest average of $\mathrm{pH}$ value of laying hens was T0 or control that was 5.94 and the lowest was in $\mathrm{T} 2$ or marination using $50 \mathrm{~g}$ of Garciniaatroviridis $+750 \mathrm{~mL}$ aquadest, namely 5.74. The results of analysis of variance showed that the control (T0) was significantly different ( $\mathrm{P}<0.05)$ with marideconcentrations of $\mathrm{T} 1$, T2 and T3. Based on the Duncan test, the marinated meat using Garcinia atroviridis had a lower $\mathrm{pH}$ value than the control and significantly affected it.

The $\mathrm{pH}$ value that had decreased with the increasing concentration Garcinia atroviridis is thought to be caused by the content of organic acids, namely citric acid and ascorbic acid, which hydrolyze the protein of culled chicken meat. Organic acids in Garcinia atroviridis can break down meat proteins by breaking peptide bonds to produce simpler proteins. Organic acids also catalyze hydrolysis reactions that involve water element. Citric acid contained in Garcinia atroviridis can hydrolyze peptide bonds in proteins into simpler amino acids. According to Hilmiati et al. (2016), marinade with organic acid-based materials can lower $\mathrm{pH}$ value of meat so that the number of bacteria would reduce thus extend the shelf life of meat

The decrease in the number of bacteria due to acid-based marinade is caused by the accumulation of Hydrogen $(\mathrm{H}+)$ ions which are toxic to bacteria. Hydrogen ions will be released by bacterial cells that need adenosine triphosphate. The more accumulations of Hydrogen ions in bacterial cells, the more adenine triphosphate has to remove these ions so that the bacteria will be short of adenine triphosphate that ultimately inhibits bacterial growth. There are several reasons that cause the decrease of $\mathrm{pH}$ value in meat such as microbial activity and acidbased marinade.

The higher concentration of organic acid-based marinade, the lower $\mathrm{pH}$ of the meat, although it is not too low. Purnamasari et al. (2013) stated that the $\mathrm{pH}$ value of culled layer hens immersed in an acid-based marinade, namely pineapple peel extract, was in the range of 5.76-5.56.

Pearson and Dutson (2004) stated that the $\mathrm{pH}$ value of meat 5.6. Lyon et al. (1991) stated that the $\mathrm{pH}$ value of chicken meat at $24 \mathrm{~h}$ was around 5.75. Meat can be categorized as moderate DFD or dark, compact and dry if it is above normal $\mathrm{pH}$. The normal $\mathrm{pH}$ value of meat is 5.5-5.8, it means that the $\mathrm{pH}$ of the treated meat in this study was included in the normal category. In this study, the marinade of $50 \mathrm{~g}$ of Garcinia atroviridis $+1000 \mathrm{~mL}$ of aquadest (T1) was the most effective way in maintaining the $\mathrm{pH}$ value of culling chicken meat.

\section{Cooking loss in culled chicken meat after marination using Garcinia atroviridis}

Cooking loss percentage value is the weight loss of meat after it went through the cooking process. The results showed that the control (T0) was significantly different $(\mathrm{P}<0.05)$ with $\mathrm{T} 2$ but not significantly different from $\mathrm{T} 1$ and $\mathrm{T} 3$. The results showed that the highest cooking loss value was in culled chicken meat after marinating Garcinia atroviridis on the control (T0), namely without marination using Garcinia atroviridis and the smallest cooking loss value for marination in $50 \mathrm{~g}$ of Garcinia atroviridis $+750 \mathrm{~mL}$ aquadest (T2), namely $21.56 \% \mathrm{~T} 1$, namely marination in $50 \mathrm{~g}$ of Garcinia atroviridis $+1000 \mathrm{~mL}$ aquadest amounting to $25.76 \%$. Based on the Duncan test, the result of cooking loss value of meat marinated using Garcinia atroviridis was lower than the control.

The concentration of Garcinia essentials containing organic acids has an effect on cooking loss. It is associated with a lower $\mathrm{pH}$ value in the treatment compared to the control (T0). A low meat $\mathrm{pH}$ value absorbs higher moisture and binds to proteins above or below the isoelectric point (approximately $\mathrm{pH}$ 5.2). This resulted in the marinade-based organic acid would absorb 
more moisture during marination resulting in a lower cooking loss (Aktas et al., 2003). Marination would make the culled chicken meat juicier. Seus and Martin (1993) stated that low levels of hydration of myofibrillar proteins at isoelectric points can cause a decrease in cooking loss during cooking. Cooking loss in $\mathrm{T} 1$ and $\mathrm{T} 2$ treatments were lower than $\mathrm{T} 0$ and associated with lower $\mathrm{pH}$ values. According to Rao et al., (1989), the effect of acid on meat muscle tissue depends on the type of fiber as well as final acidification. Marinade with weak acids causes swelling of collagen surrounding the bundles of muscle fibers (perimysium) and single fibers (endomysium).

This means it relates to electrostatic and osmotic theories about muscle swelling. The addition of organic acids as a marinade in meat muscleswill result in the protonation of carboxyl groups. According to electrostatic theory, the addition of acids below the isoelectric point of meat proteins will gradually protonate negatively charged carboxyl groups that should sever electrostatic bonds with adjacent protein chains. The increases in the positive charge are estimated to resultin repulsion between the two protein groupswith the same charge, thus creating room for immobilization and water addition.

Whereas in the osmotic theory, acid anions form ionized salts with available cationic groups on protein molecules resulting in an unevendistribution of free ions between proteins and surrounding acid solutions. This causesdifferences in osmotic pressure. Water will flow into the protein structure of the meat and eventually cause the occurrence of muscle swelling (Seus and Martin., 1993). T3 is the maximum limit for the concentration of marinade that enters the protein structure of the meat so that after the swelling of the muscle fibers, the water will come out faster and cause higher cooking loss than $\mathrm{T} 1$ and $\mathrm{T} 2$.

Marination with $50 \mathrm{~g}$ of Garcinia atroviridis $+750 \mathrm{~mL}$ aquadest (T2) was effective to reduce the value of cooking loss in culled meat. According to Obuz et al.
(2004), a high cooking loss value is related to muscle fibers and collagen tissue shrinkage in meat. Cooking loss may be influenced by $\mathrm{pH}$ value, sarjomer length, sample size and weight and heating (Dewayani et al., 2015). The value of cooking loss in this study was still in the normal category and was lower than the study conducted by Pelicano et al. (2003) that the cooking loss in chicken carcasses ranged from $28.82 \%$ to $29.90 \%$.

\section{Drip loss of culled chicken meat after marination using Garcinia atroviridis}

Drip loss is the liquid meat that comes out along with meat nutrients that dissolve and lost during the storage process where the meat is usually hung (Patriani et al., 2020). Dripping meat surface liquid (drip). Otto et al. (2004) stated that the drip loss had an average percentage of $4.97 \%$. The results showed that (T0) was significantly different $(\mathrm{P}<0.05)$ with $\mathrm{T} 1$ and $\mathrm{T} 2$ but and not significantly different $(\mathrm{P}>0.05)$ with $\mathrm{T} 3$. The highest drip loss value was (T3), namely $3.79 \%$, followed by control (T0), namely $3.35 \%$ and (T2) with a value of 2.91. The lowest value on marination in $50 \mathrm{~g}$ of Garcinia atroviridis $+500 \mathrm{~mL}$ aquadest (T1) was $2.40 \%$. In $\mathrm{T} 3$ the drip loss had increased because the acid concentration was more concentrated so that it can dissolve the fat on the surface of the meat that drips altogether with meat water.

The organic acid content in the marinade will dissolve fat, therefore the fat on the surface of meat will drip alongside meat water during hanging process. Nolsoe and Undeland (2009) reported that acids can reduce fat in meat. It is because organic acid solution is strong enough to break the bonding structure of proteins, which will bind fat molecules until the fats are wasted and the fat contentsc decrease. Storage and cooling time in the refrigerator can also affect drip loss. The T3 treatment had the highest drip loss because the concentration of Garcinia atroviridis was higher than the other treatments so that the organic acid content was stronger in breaking the protein 
bond structures that bind the fat molecules thus the fat in meat fibers were reduced more than the other treatments.

In the $\mathrm{T} 1, \mathrm{~T} 2$, and $\mathrm{T} 3$ treatments, it can be seen that the higher concentration of Garcinia atroviridis marinade, then the higher drip loss in the culled chicken meat. The drip loss in the study was included in the normal level. In addition to that, the drip loss in this study was lower than the one reported by Wiklund et al. (2008) that drip loss of meat in the first week of withering was $4.1 \%$. According to Dufal et al. (1999) stated that the average drip loss during postmortem 3$10 \mathrm{~d}$ can reach 2.04 - 5.19. Marination in $50 \mathrm{~g}$ of Garcinia atroviridis $+1000 \mathrm{~mL}$ aqua dest (T1) was effective in reducing meat drip loss. Overall, the drip loss values in the treatments were still in a good range.

\section{Water Holding Capacity of culled chicken meat after marination using Garcinia atroviridis}

Water holding capacity is the ability of meat to retain water content in meat against external influences. WHC is the ability of meat to bind water because the electrolyte of water molecules is not neutral but has positive and negative charges, so that water molecules can bind to protein groups. The results showed that the control (T0) was significantly different $(\mathrm{P}<0.05)$ with $\mathrm{T} 1$ on WHC. The control (T0) was also significantly different $(\mathrm{P}<0.01)$ with $\mathrm{T} 2$ and T3. The highest water holding capacityvalue was at T3 and the lowest water holding capacity value was at $\mathrm{T} 0$ that is without marination.

Based on the Duncan test that the higher concentration of Garcinia atroviridis will increase Water Holding Capacity of culled chicken meat. Level of Garcinia atroviridis concentration may increase water holding capacity because the higher level of Garcinia atroviridis concentration, that would mean the more organic acids work and ion diffusion occurs in meat protein. Consequently marinades using Garcinia atroviridis can increase the ability of the meat to bind free water. In linewith the
Lemos et al. (1999) study that immersion techniques can increase water content in poultry meat. Water holding capacity has increased gradually, namely at $\mathrm{T} 1$ of $42.58 \%$, then there was an increase inT2 that was $50.08 \%$ and continued to increase until $\mathrm{T} 3$, namely $54.06 \%$. It is because marination using acids, especially Garcinia atroviridis in T1, T2 and T3 can increase water holding capacity and acidcontent in the marination method causing the meat to absorb more water. Most of the meat is in the muscles and trapped in the cell structure including the intra-cell space. Therefore, changes in intracellular cells affect the ability of muscle cells to retain water. The higher water holding capacity, then the better meat quality.

Lonergan and Lonergan (2005) stated that the decrease in $\mathrm{pH}$, proteolytic, and oxidation during storage may affect water holding capacity. Most of the water in the muscles is also trapped in the cell structure including the intra and extra myofibrillar spaces that ultimately affect the muscle cells to hold water. In the study the higher concentration of Garcinia atroviridis increased the water holding capacity. This means that the marinade concentration treatment using Garcinia atroviridis resulted in higher waterholding capacity because a lot of bound water is retained from the meat protein.

The Increase of water holding capacity in marinated meat can be caused by the abilityof muscle types to bind water and differences in protein solubility in each type of muscle. Lawrie (2015) stated that the ability of the meat to bind water is influenced by the protein content in the veins of meat/ tendon, intrinsic differentiation factors in the tendon, and the content of water-soluble sarcoplasm proteins. In this study, the $\mathrm{pH}$ values of the treatments from $\mathrm{T} 1$ to $\mathrm{T} 3$ in the range of 5.74 - 5.77 indicated that the $\mathrm{pH}$ values were higher than the isoelectric $\mathrm{pH}$ of meat (5.05.1). The more $\mathrm{pH}$ value approaches an isoelectric point, the value of water holding capacity gets smaller and vice versa, if the 
$\mathrm{pH}$ value of meat above the isoelectric $\mathrm{pH}$ value, then the higher value of water holding capacity (Haq et al., 2015).

The $\mathrm{pH}$ value ofthe meat that remains high and slow declines can also lead water holding capacity to increase (Lawrie., 2015). According to this study Marination in $50 \mathrm{~g}$ of Garcinia atroviridis $+1000 \mathrm{~mL}$ aqua dest (T1) was effective in increasing the Water Holding Capacity of culled chicken meat.

\section{The tenderness of the culled chicken meat after marination using Garcinia atroviridis}

The tenderness of the meat can be tested using a tool or organoleptic test that involves the sense of taste, but in this study, a penetrometer was involved. Meat tenderness can be an indicator to determine meat quality. In addition to that, tender meat is easier to be masticated and digested by the body. The results showed that the control (T0) was significantly different $(\mathrm{P}<0.05)$ against $\mathrm{T} 2$ and $\mathrm{T} 3$ was significantly different $(\mathrm{P}<0.01)$ from $\mathrm{T} 1$ for tenderness. The value of the tenderness of the culled cicken meat in the control was lower that was $37.83 \mathrm{~g} /$ 10 ss than T3 treatment that was $30.76 \mathrm{~g} /$ 10 ss, T2 was $30.55 \mathrm{~g} / 10$ ss and T1 was $24.63 \mathrm{~g} / 10 \mathrm{ss}$.

Garcinia atroviridis marination can increase the value of tenderness compared to control. Apart fromthis, the acid contained in Garcinia atroviridis is thought to reduce bacterial growth. According to Burke and Monahan (2003), marinade that contains vitamin $\mathrm{C}$ and malic acid can optimally increase meat tenderness. Garcinia atroviridis contains citric acid, malic acid, and ascorbic acid so that it has the potential to become an acid- based marinade. The tenderness values at $\mathrm{T} 2, \mathrm{~T} 3$ and $\mathrm{T} 1$ were lower than T0. It is due to the fact that the organic acid concentration in Garcinia atroviridis at the right concentration was able to break the peptide bonds in the protein fiber of meat.

Aligned with Burke and Monahan (2003) These acids can reduce the peptide bonds in meat fiber protein so that the meat is more tender. The lower breaking power value of the meat, the more tender meat will be and the higher breaking power value, more tough the meat will be. In the study, the lowest value on T1 was marination in $50 \mathrm{~g}$ of Garcinia atroviridis $+1000 \mathrm{~mL}$ aquadest (T1) which was effective in increasing the tenderness of the culled chicken. Burke and Monahan (2003) that marinating meat in lemon juice, orange juice and aquadest can change meat tenderness.

\section{The color of the culled chicken meat after marinating using Garcinia atroviridis}

The color of the meat can be tested using a color tester tool, a colorimeter. The results of this study can be seen in Table 2 . Fresh poultry has a different color than those that are no longer suitable for consumption. Color characteristics used the $\mathrm{L}^{*}, \mathrm{a}^{*}$ and $\mathrm{b}^{*}$ methods to distinguish dark and light colored poultry meat (Boulianne and King, 1998).

Table 2. Color of culled chicken meat after marination using Garcinia atroviridis

\begin{tabular}{|c|c|c|c|c|c|}
\hline \multirow[t]{2}{*}{ Parameter } & \multicolumn{4}{|c|}{ Treatment of Garcinia atroviridis Concentration } & \multirow[t]{2}{*}{ Average } \\
\hline & T0 & $\mathrm{T} 1$ & $\mathrm{~T} 2$ & T3 & \\
\hline $\begin{array}{l}\text { Meat Color } \\
\left(\mathrm{L}^{*}\right)\end{array}$ & $55.33 \pm 4.19^{\mathrm{a}}$ & $65.55 \pm 2.10^{\mathrm{b}}$ & $62.44 \pm 6.46^{\mathrm{b}}$ & $63.98 \pm 2.96^{\mathrm{b}}$ & $61.82 \pm 5.46^{\mathrm{b}}$ \\
\hline$\left(a^{*}\right)$ & $13.04 \pm 2.57^{\mathrm{a}}$ & $3.99 \pm 0.47^{b}$ & $4.71 \pm 0.41^{b}$ & $5.93 \pm 2.38^{b}$ & $6.92 \pm 4.06^{\mathrm{b}}$ \\
\hline$\left(b^{*}\right)$ & $21.40 \pm 2.26$ & $18.42 \pm 0.37$ & $17.10 \pm 1.42$ & $17.48 \pm 1.19$ & $18.60 \pm 2.16$ \\
\hline
\end{tabular}


The results of the analysis of variance showed that the T0 treatment was significantly different $(\mathrm{P}<0.05)$ with $\mathrm{T} 1, \mathrm{~T} 2$ and $\mathrm{T} 3$ on brightness. The average brightness ( $\left.\mathrm{L}^{*}\right)$ or Light of culled chicken meat in both T1, T2 and T3 treatments had higher brightness when compared to meat samples without treatment or control. The brightness level $\left(\mathrm{L}^{*}\right)$ of the meat in the marinated meat used Garcinia atroviridis was higher than the control. Lawrie (2015) stated that proteindenaturation and physical appearance of meat depend on postmortem temperature and $\mathrm{pH}$ that affects the amount of light reflected from the inside to the outside of the meat. This is due to the scattering of light which is directly proportional to the degree of denaturation of proteins.

The scattering of light can affect L (Light) or the brightness of the meat. Rimini et al., (2014) specified thatthe brightness of chicken meat that was marinated using orange and thyme essentialoil was between 50.61-50.57. In this study, the value of Light rangedfrom 55.33-63.98. The range fell into the fairly bright category. Chicken meat is considered as white meat and marinating meat using Garcinia atroviridis willincrease the brightness of meat color.Marination in $50 \mathrm{~g}$ of Garcinia atroviridis $+1000 \mathrm{~mL}$ aquadest (T1) effectively lightenedthe meat color.

The results of analysis of variety showed that the T0 treatment had a significant effect $(\mathrm{P}<0.05)$ to $\mathrm{T} 1, \mathrm{~T} 2$ and $\mathrm{T} 3$ on the reddish color $\left(\mathrm{a}^{*}\right)$ of the culled chicken meat on (T0) or the control was higher than other treatments, namely T1, T2 and T3. In chicken, the higher the red color (a*) showed that the meat was less fresh. In this study, the meat of the culled chicken in sample T0 has a redder color than the meat in samples T1, T2 and T3.

This means that marination using Garcinia atroviridis can maintain the freshness and quality of meat because the acid in Garcinia atroviridis is presumed to contain anti-microbial compounds. Rahayu et al., (2020) stated that the color of the meat at the yellowish level $(\mathrm{b} *)$ for marination treatment using kecombrang stem flour was between 4.44-5.59. Whereas the sample in this study had yellowish levels of 5.74-5.77. Marination in $50 \mathrm{~g}$ of Garcinia atroviridis + $1000 \mathrm{~mL}$ aquadest (T1) is effective in maintaining the freshness of the meat. The content of $b^{*}$ color or yellowish color did not show a significant difference $(\mathrm{P}>0.05)$ on the color of the meat.

The results of the analysis of variance showed that the treatment of T0 was significant $(\mathrm{P}<0.05)$ with $\mathrm{T} 1, \mathrm{~T} 2$ and $\mathrm{T} 3$ on color $b^{*}$. The yellowish color of fresh chicken meat ishigher than carcass chicken. Marination canaffects the higher $\mathrm{L}^{*}, \mathrm{a} *$ and b* colors during storage (Zhang et al., 2016) The color intensity in the treatment was lower than the control, presumably because the effect of the acid contained in Garcinia atroviridis greatly affected the color of the meat which was cleaner, brighter, and fresher than the control.

\section{CONCLUSION}

According to the results derived from the research and discussion, it can be inferred that the concentration in the Garcinia atroviridis marinade has an influence on $\mathrm{pH}$, cooking loss, water holding capacity, drip loss, tenderness and color brightness (L), reddish color of the meat $\left(\mathrm{a}^{*}\right)$ but does not affect the yellowish color of the meat $\left(b^{*}\right)$. The optimal concentration of Garcinia atroviridis that can be used as marinade for chicken meat is $50 \mathrm{~g}$ of Garcinia atroviridis $+750 \mathrm{~mL}$ of aquadest.

\section{ACKNOWLEDGMENT}

Authors would like to thank the Universitas Sumatera Utara and the Universitas Sumatera Utara Research Institute. This research was funded by the Universitas Sumatera Utara Research Institute in accordance with the Talent Research Agreement Letter of the Universitas Sumatera Utara for the 2020 
Fiscal Year, Number: 4142 / UN.5.1.R / PPM / 2020, dated 27 April 2020

\section{REFERENCES}

Abdullah, A. R., Bakhari, N. A., \& Osman, H. (2013). Study on the relationship of the phenolic, flavonoid and tannin content to the antioxidant activity of garcinia atroviridis. Universal Journal of Applied Science, 1(3), 95-100. https:// doi.org/10.13189/ujas.2013.010304

Aktaş, N., Aksu, M. I., \& Kaya, M. (2003). The effect of organic acid marination on tenderness, cooking loss and bound water content of beef. Journal of Muscle Foods, 14(3), 181-194. https: //doi.org/10.1111/j.1745-4573.2003.t b00699.x

Al-Mansoub, M. A., Asmawi, M. Z., \& Murugaiyah, V. (2014). Effect of extraction solvents and plant parts used on the antihyperlipidemic and antioxidant effects of Garcinia atroviridis: a comparative study. Journal of the Science of Food and Agriculture, 94(8), 1552-1558. https: //doi.org/10.1002/jsfa.6456

AOAC. (2005). Official Methods of Analysis. Association of Official Analytical Chemists.

Berri, C., Besnard, J., \& Relandeau, C. (2008). Increasing dietary lysine increases final $\mathrm{pH}$ and decreases drip loss of broiler breast meat. Poultry Science, 87(3), 480-484. https://doi. org/10.3382/ps.2007-00226

Boulianne, M., \& King, A. J. (1998). Meat color and biochemical characteristics of unacceptable dark-colored broiler chicken carcasses. Journal of Food Science, 63(5), 759-762. https://doi.org /10.1111/j.1365-2621.1998.tb17894.x

Burke, R. M., \& Monahan, F. J. (2003). The tenderisation of shin beef using a citrus juice marinade. Meat Science, 63(2), 161-168. https://doi.org/10.10 16/S0309-1740(02)00062-1

Dewayani, R., Natsir, M., \& Sjofjan, O. (2015). Effect of using tapioca by- product and tofu waste fermented with a mix culture of aspergillus niger and rhizopus oligosporus as a substitute for corn on physical qualities by broiler. Jurnal Ilmu Dan Teknologi Hasil Ternak, 10(1), 9-17. https://doi. org/10.21776/ub.jitek.2015.010.01.2

Hafid, H., Patriani, P., Nuraini, Norma, Ananda, S. H., \& Inderawati. (2020). Organoleptic characteristics of broiler chicken meat using juice of starfruit ( Averrhoa bilimbi L). IOP Conference Series: Earth and Environmental Science, 454(1), 012057. https://doi.org /10.1088/1755-1315/454/1/012057

Hakim, U., Rosyidi, D., \& Widati, A. (2013). The effect of arrowroot flour (maranta arrundinaceae) on physical and sensoric qualitiy of rabbit nugget. Jurnal Ilmu Dan Teknologi Hasil Ternak, 8(2), 9-22. https://doi.org/ 10.21776/ub.jitek.2013.008.02.1

Hamm, R. (1961). Biochemistry of meat hydration. Journal of Food, 10, 355463. https://doi.org/10.1016/S00652628(08)60141-X

Haq, A. N., Septinova, D., \& Santosa, P. E. (2015). The physical of beef from traditional market in Bandar Lampung. Jurnal Ilmiah Peternakan Terpadu, 3(3), 98-103.

Hilmiati, Nurliana, Ismail, Husnurrizal, Razali, Darmawi, \& Hambal, M. (2016). The immersion effect of broiler carcass in citric acid and acetic acid on spoilage process inhibition. Jurnal Medika Veterinaria, 10(2), 133-136. https://doi.org/10.21157/j. med.vet..v10i2.4626

Huff-Lonergan, E., \& Lonergan, S. M. (2005). Mechanisms of water-holding capacity of meat: The role of postmortem biochemical and structural changes. Meat Science, 71(1), 194-204. https://doi.org/10.10 16/j.meatsci.2005.04.022

Kaewthong, P., \& Wattanachant, S. (2018). Optimizing the electrical conductivity of marinade solution for waterholding capacity of broiler breast 
meat. Poultry Science, 97(2), 701-708. https://doi.org/10.3382/ps/pex334

Lawrie, R. A. (2015). Meat Science. Universitas Indonesia Press.

Le Bihan-Duval, E., Millet, N., \& Remignon, H. (1999). Broiler meat quality: effect of selection for increased carcass quality and estimates of genetic parameters. Poultry Science, 78(6), 822-826. https://doi.org/10.1093/ps/78.6.822

Lemos, A. L. S. C., Nunes, D. R. M., \& Viana, A. G. (1999). Optimization of the still-marinating process of chicken parts. Meat Science, 52(2), 227-234. https://doi.org/10.1016/S0309-1740(9 8)00172-7

Lomiwes, D., Farouk, M. M., Wu, G., \& Young, O. A. (2014). The development of meat tenderness is likely to be compartmentalised by ultimate pH. Meat Science, 96(1), 646-651. https://doi.org/10.1016/j.me atsci.2013.08.022

Nolsøe, H., \& Undeland, I. (2009). The acid and alkaline solubilization process for the isolation of muscle proteins: state of the art. Food and Bioprocess Technology, 2(1), 1-27. https://doi. org/10.1007/s11947-008-0088-4

Novita, R., Sadjadi, S., Karyono, T., \& Mulyono, R. (2019). Level ekstrak buah nanas (Ananas Comosus L. Merr) dan lama perendaman terhadap kualitas daging itik afkir. Jurnal Peternakan Indonesia (Indonesian Journal of Animal Science), 21(2), 1020-1025. https://doi.org/10.25077/ jpi.21.2.143-153.2019

Nur Allisha, O., Zaulia, O., Mohd Shukri, M. A. I., Suriani, M. N., Nur Syafini, G., Azhar, M. N., Khdijah, R., Razali, A. R., Mohd Azhar, R., Nur Izzati, M., Siti Nur Raihan, A., Razali, M., Salma, I., Khadijah, A., \& Mohd Nor Faizal, G. (2020). Development of garcinia atroviridis (Asam Gelugur) during fruit growth. Journal of Advanced Research in Materials Science, 73(1), 12-20. https://doi.org/

\subsection{4/arms.73.1.1220}

Nurfi, N., \& Sopandi, T. (2014). Degradasi kandungan formalin pada daging ayam Broiler (Gallus domesticus) berformalin dengan perendaman larutan lidah buaya (Aloe vera). Jurnal Matematika Dan Ilmu Pengetahuan Alam Unipa, 7(02), 1217. https://doi.org/10.36456/STIGMA .VOL7.NO2.A518

Nurwantoro, N., Bintoro, V. P., Legowo, A. M., Purnomoadi, A., Ambara, L. D., Prakoso, A., \& Mulyani, S. (2012). Nilai Ph, kadar air, dan total escherichia coli daging sapi yang dimarinasi dalam jus bawang putih. Jurnal Aplikasi Teknologi Pangan, 1(2).

Obuz, E., Dikeman, M., Grobbel, J., Stephens, J., \& Loughin, T. (2004). Beef longissimus lumborum, biceps femoris, and deep pectoralis WarnerBratzler shear force is affected differently by endpoint temperature, cooking method, and USDA quality grade. Meat Science, 68(2), 243-248. https://doi.org/10.1016/j.meatsci.200 4.03.003

Otto, G., Roehe, R., Looft, H., Thoelking, L., \& Kalm, E. (2004). Comparison of different methods for determination of drip loss and their relationships to meat quality and carcass characteristics in pigs. Meat Science, 68(3), 401-409. https://doi.org/10.10 16/j.meatsci.2004.04.007

Patriani, Hafid, \& Mirwandhono, E. (2019). Kualitas Daging Domba dengan Penerapan Teknologi Marinasi Menggunakan Kluwak Fermentasi terhadap Masa Simpan. Prosiding Seminar Nasional Teknologi Peternakan Dan Veteriner 2019, 491499. https://doi.org/10.14334/Pros.Se mnas.TPV-2019-p.491-499

Patriani, P., Mirwandhono, E., Wahyuni, T. H., Siregar, G. A. W., Hasanah, U., Hasnudi, Ginting, N., \& Yunilas. (2020). Effect of kepayang ( Pangium edule ) seed extract on meat moisture content, drip loss and decay test of 
lamb meat at different shelf life. Journal of Physics: Conference Series, 1542(1), 012-029. https://doi.org/10.10 88/1742-6596/1542/1/012029

Pearson, A. M., \& Dutson, T. R. (1994). Introduction to quality attributes and their measurement in meat, poultry and fish products. In Quality Attributes and their Measurement in Meat, Poultry and Fish Products (pp. 1-33). Springer US. https://doi.org/ 10.1007/978-1-4615-2167-9_1

Pelicano, E., Souza, P. de, Souza, H. de, Oba, A., Norkus, E., Kodawara, L., \& Lima, T. de. (2003). Effect of different probiotics on broiler carcass and meat quality. Revista Brasileira de Ciência Avícola, 5(3), 207-214. https://doi.org/ 10.1590/S1516-635X2003000300009

Prayitno, S. S., Sumarmono, J., \& Rahardjo, A. H. D. (2020). Pengaruh lama perendaman daging itik afkir pada ekstrak kulit buah carica (Carica Candamarcensis) terhadap keempukan dan susut masak daging. Jurnal Peternakan Nusantara, 6(1), 15-20. https://doi.org/10.30997/jpnu.v6i1.1815

Purnamasari, E., Putri, R., \& Handoko, J. (2013). The physical properties of soaked buffalo meat with liquid smoke and citric acid at different concentrations. Sagu, 12(1), 1-7.

Rahayu, P. I. S., Miwada, I. N. S., \& Okarini, I. A. (2020). Efek marinasi ekstrak tepung batang kecombrang terhadap sifat fisik dan organoleptik daging broiler. Majalah Ilmiah Peternakan, 23(3), 118-123. https://doi. org/10.24843/MIP.2020.v23.i03.p04

Rao, M. V., Gault, N. F. S., \& Kennedy, S. (1989). Variations in water-holding capacity due to changes in the fibre diameter, sarcomere length and connective tissue morphology of some beef muscles under acidic conditions below the ultimate $\mathrm{pH}$. Meat Science,
26(1), 19-37. https://doi.org/10.1016/ 0309-1740(89)90054-5

Rimini, S., Petracci, M., \& Smith, D. P. (2014). The use of thyme and orange essential oils blend to improve quality traits of marinated chicken meat. Poultry Science, 93(8), 2096-2102. https://doi.org/10.3382/ps.2013-03601

Seuss, I., \& Martin, M. (1993). The influence of marinating with food acids on the composition and sensory properties of beef. Fleischwirtsch, 73, 292-295.

Steel, R. G., \& Torrie, J. H. (1990). Prinsip dan Prosedur Statistik Suatu Pendekatan Biometrik. Gramedia.

Wideman, N., O’Bryan, C. A., \& Crandall, P. G. (2016). Factors affecting poultry meat colour and consumer preferences - A review. World's Poultry Science Journal, 72(2), 353-366. https://doi. org/10.1017/S0043933916000015

Wiklund, E., Finstad, G., Johansson, L., Aguiar, G., \& Bechtel, P. J. (2008). Carcass composition and yield of Alaskan reindeer (Rangifer tarandus tarandus) steers and effects of electrical stimulation applied during field slaughter on meat quality. Meat Science, 78(3), 185-193. https://doi. org/10.1016/j.meatsci.2007.06.004

Zhang, H., Wu, J., \& Guo, X. (2016). Effects of antimicrobial and antioxidant activities of spice extracts on raw chicken meat quality. Food Science and Human Wellness, 5(1), 39-48. https://doi.org/10.1016/j.fshw.2015.1 1.003

Zhang, Y., Zhang, D., Huang, Y., Chen, L., Bao, P., Fang, H., Xu, B., \& Zhou, C. (2020). Effects of basic amino acid on the tenderness, water binding capacity and texture of cooked marinated chicken breast. LWT, 129, 109524. https://doi. org/10.1016/j.lwt.2020.109524 